\title{
Nurses' Perception of Causes of 2015 Strikes at Federal Medical Centre Owerri: Implication for Preventive Strategies
}

\author{
Bridget Omowumi Akin-Otiko ${ }^{1,}$, , Modupe Motunrayo Adamolekun ${ }^{1}$, Julie Remilekun Amoka ${ }^{2}$ \\ ${ }^{1}$ Department of Maternal, Neonatal \& Child Health Nursing, University of Medical Sciences, Ondo-City, Nigeria \\ ${ }^{2}$ Kaduna State College of Midwifery, Kaduna, Nigeria
}

Email address:

wumiakinotiko@yahoo.com (B. O. Akin-Otiko), dupeekundayo82@gmail.com (M. M. Adamolekun), amokajr@gmail.com (J. R. Amoka)

${ }^{*}$ Corresponding author

\section{To cite this article:}

Bridget Omowumi Akin-Otiko, Modupe Motunrayo Adamolekun, Julie Remilekun Amoka. Nurses' Perception of Causes of 2015 Strikes at Federal Medical Centre Owerri: Implication for Preventive Strategies. International Journal of Health Economics and Policy.

Vol. 4, No. 4, 2019, pp. 132-142. doi: 10.11648/j.hep.20190404.13

Received: May 24, 2019; Accepted: June 26, 2019; Published: November 5, 2019

\begin{abstract}
Get the nurses to go back to work" was the directive, after two years of intermittent labour strikes and consequent shutdown of the Federal Medical Centre, Owerri, South Eastern Nigeria. It was assumed that, since nurses constituted the largest percentage of health workers, their resumption would frustrate and end the strike. However, studies have shown that the use of force rarely worked. This study examined the nurses' perception of causes of the strikes and the government interventions. The WHO healthy workplace framework was adapted in recommending strategies to prevent reoccurrence. Exploratory research design with mixed method sequential exploratory data collection strategy was utilized. Findings from focus group discussions in first phase were used to develop Likert scale self-administered questionnaire at second quantitative phase. One hundred and thirtynine and 461 nurses participated in the qualitative and quantitative phases respectively. Epi Info statistical package was used for data entry and analysis of the quantitative data. Frequencies and percentages were calculated for all the items, and Chi-square was calculated between the senior and junior nurses' responses. The responses of the senior and junior nurses were similar on the items. All sixteen causes of the strike identified by participants were within Psychosocial Work Environment of the WHO framework. Disparity in salary was highest (443(96.1\%), followed by highhandedness of the chief executive (436(94.58\%). Participants opined that insincerity of the investigation panel $(369(80 \%)$ and seriousness of the crisis led to the shutdown (341(73.97\%) of the facility. Suggested fifteen preventive strategies against strikes covered two of the WHO's workplace environments. They included, the psychosocial environment: effective communication (450(97.61\%), promotion of nurses as and when due (447(96.96\%), harmonization of salaries (445(96.53\%), change of chief executive (442(95.87\%); and the physical environment: provision of materials to work with in the hospital (406(88\%). Accurate reports by panels of enquiry (448(97.18\%), appropriate prompt attention to the causes $(447(96.96 \%)$, and avoidance of sentiments (446(96.75\%) could prevent repeat shutdown of the facility. Chi-square showed no significant difference in the responses of the senior and junior nurses. According to the WHO healthy work place intervention model, elimination, substitution and modification of contents and processes in the workplace may be required. Stakeholders should avoid factors that hinder appropriate interventions; and uphold values that protect workers and the benefitting communities.
\end{abstract}

Keywords: Nurses, Healthy Workplace, Strikes, Industrial Actions, Preventive Strategies, FMC

\section{Introduction}

\subsection{Background}

Conflicts are inevitable as long as people coexist [1], and they are unavoidable in workplaces [2]. However, industrial actions in Nigeria's health sector are unacceptably on the increase, making government prompt intervention inevitable [3]. Strike is a form of industrial action. Workers are said to be on strike when they refuse to work completely or work 
below efficiency level, in order to compel their employers to attend to their demands [4-5]. Strike is the most employed form of industrial action [6]. Not only the workers get involved in the ensuing crisis; other stakeholders are involved one way or the other [7-8]. Usually, during industrial crises, health care services are not completely paralyzed in any health institution since there are different professionals and they belong to their respective unions [9]. However, with the coming together of a number of unions to form the Joint Health Sector Unions (JOHESU) in Nigeria, industrial actions in the health sector by JOHESU have been widespread and formidable.

The code of ethics of the nursing profession requires them to act in the best interest of their clients / patients [10-11]; hence, in spite of their rights to industrial actions, the public often expects them to consider the ethics of the profession above their rights. Understandably, this is because nurses constitute the largest single group of professionals in the health sector [12-13], and in FMC Owerri, they are about $28 \%$ of the entire workforce. Nurses have been described as the backbone [14] and workhorses of health facilities [12]. Nurses provide twenty-four hour care for patients in the hospital and almost all aspects of the patients' care in the health facility require a measure of nursing care [13]. Nurses in Nigeria belong to the National Association of Nigeria Nurses and Midwives - NANNM, an affiliate of the Joint Health Sector Unions (JOHESU) and the National Labour Congress - NLC [15].

Unions provide avenue for workers to express their dissatisfactions and be heard [16]. Industrial action guidelines differ from one country to another [5]. As critical as the health sector is, the workers too have rights to industrial action which should not be denied them [4-5]. Services that when withdrawn pose a threat to the safety, health and life of the citizens are termed essential [5].

\subsection{Causes of Industrial Crisis}

Oleribe, et al [18] observed that less than half of health workers favoured industrial actions. Participation of health professionals in industrial actions depends on the influencers [19]. Causes of industrial crisis include: failure of government to implement agreements [20] from previous negotiations [21]; poor conditions of service [2, 20], including threats to workers' health [22]; management's misinterpretation of contract agreement between government and the workers [23]; poor and discriminatory remuneration $[2,23]$; absence of teamwork and corruption [23]; economic recession making compromise difficult during negotiations; lack of promotions; delay in salaries of newly employed staff; poor management-worker relationship; inadequate information on labour laws; non-enforcement of the nowork-no-pay law; ineffective communication system; lack of trust [24]; and maltreatment of workers [2] by the management. In the past, salary related strike accounted for $50 \%$ [22] of industrial actions, and in recent times, it could be as high as $82 \%$ [18]. In the Nigerian health sector, poor health care leadership and management was documented as the commonest and most important cause of industrial action [18].

\subsection{Consequences of Industrial Actions Especially in the Health Sector}

Industrial actions negatively affect the entire health system leading to increasing medical tourism [25]. The major consequence of industrial actions is, "... tragic but avoidable loss of human life, value of which cannot be accurately computed" [26]. Others include: bad image of the particular health institution and the whole country, loss of internally generated revenue [20], and public lack of access to quality health care [18]. As undesirable as strikes are, they are capable of providing opportunities [7] for understanding of the underlying issues and establishing quality employeremployee relationships [24].

\subsection{Prevention and Control of Industrial Action}

Although conflicts are inevitable and the rights of workers in the health sector to industrial action cannot be denied, efforts should be made to avoid industrial action and promote alternative means of resolving crisis [4]. Employers and managers should realize the imminence of crisis [7] and be ready at all times to prevent an industrial action that would cripple operations, by having implementable policies [23] and mechanisms in place [8]. There is the need for mutual respect among stakeholders, and respect for the extant regulations, as well as the guiding principles put in place to promote industrial harmony and mitigate possible conflicts [27]. Appropriate application of relevant labour laws has been recommended [24:7]. It is important to note however that, harsh directives or interventions by governments are usually not effective and often worsen the crisis [9]. It was observed that temporary involvement of a third-party in industrial conflict resolution could be positive [9].

Efficient government is critical for sustainable industrial harmony in Nigeria [25]. Government should adopt fair wage policy acceptable to professionals in the health sector; and promote workplace equity and harmony [23]. Government should not agree on what they cannot implement and should honour agreements reached [16] in appreciation of the public rights to quality health care services. Enabling working conditions and health of workers are of paramount importance [2, 29] and this must be ensured.

The employees also have a significant role to play. In line with the visions of most unions to protect the public [11, 30], workers in the health sector should understand that their right to industrial action should be expressed within the dictates of their professional ethics and the general ethical principle of 'do no harm' [4]. They should find a way to provide basic and essential services to patients during strike action [18]. Skeletal services could be provided by some of the workers or by alternative sources [4] through worked out agreement with other providers. Workers should be educated on implications of frequent strike actions [20], labour laws and related skills [2]. There is also the need to appreciate the fact 
that right to industrial actions are only protected when exercised within the provisions of relevant laws [31].

\subsection{The 2015 Strikes at Federal Medical Centre, Owerri}

There was a general JOHESU nationwide total strike from November, 2014 to February, 2015. Thereafter, the Federal Medical Centre, Owerri JOHESU strike took place from $15^{\text {th }}$ May $-29^{\text {th }}$ July 2015 , and $18^{\text {th }}$ November $-4^{\text {th }}$ December, 2015. The nurses, like the other JOHESU members in the hospital were actively involved in the industrial crisis. Efforts by the supervising Federal Ministry of Health, Abuja, the State Governor and traditional institutions to mediate in the crisis failed. The Centre was therefore shutdown by the supervising ministry on $5^{\text {th }}$ December, 2015. That was the first and only time a tertiary health facility was shut down in the country under such circumstance.

Crisis management in the health sector aims, among other things, at ensuring that the health of the citizens is not jeopardized [28]. Hence, in recognition of the grave consequences of continued lack of access to quality health care by the public, the Federal Government through Federal Ministry of Health set up an Interim Management Committee (IMC) on $21^{\text {st }}$ December 2015, to take over the Management of the Centre and to restore peace and quality service in the institution [32]. The Committee had eleven Terms of Reference (TOR) including "... review of the events leading up to the industrial unrest..." [32:ii]. "Get the nurses to go back to work" was the specific directive to BOA (the nurse on the Committee). This was in recognition of the importance of this cadre of health workers to the restoration and sustenance of care services in the hospital. It was assumed that, since nurses constituted the largest percentage of health workers, their resumption would frustrate and end the strike.

To BOA, the directive to "Get the nurses to go back to work" did not presuppose the use of coercion; rather, the adoption of a process that could lead to attainment of the desired result, in a form that outlives the tenure of the Interim Management Committee (IMC). Hence, the need to employ the research process in exploring the perception of the nurses about the strikes, and working together with the nurses on the way forward to ensuring enduring solution to the protracted crisis. No such research had been carried out in the hospital or by the supervising Federal Ministry of Health among nurses in Nigeria.

\subsection{Objectives}

The study was undertaken to examine the perception of the nurses on the causes of the 2015 strikes and stakeholders' roles; with a view to recommending, strategies to prevent reoccurrence of the industrial action and its consequences.

\subsection{The WHO Healthy Workplace Framework}

The WHO Health Workplace Framework by Burton [33] was adapted for the study. According to Burton [33], many employers of labour do not appreciate the importance of healthy workplace and lack the capacity to enhance it. In line with the focus of the study, the framework deals with both the workplace content which influence its health, and the processes to improve and maintain a healthy workplace. The framework describes four interrelated core contents of the workplace, referred to as "avenues of influence". The four, must be attended to in order to have a healthy workplace. They are, the physical work environment, the psychosocial work environment, personal health resources in the workplace, and enterprise community involvement. When and how to manage the challenges identified in the four avenues of influence vary from one organization to the other, based on the results of the assessment. Suggested management of undesirables in the four avenues follow a "... a hierarchy of controls that seeks to eliminate the hazard if possible or modify it at the source; lessen the impact on the worker; or help the worker protect him or herself from its effects." [33]. In the discussion section, Burton's [33] hierarchy of controls formed the framework for organizing the strategies to prevent reoccurrence of the strikes and consequent shutdown of the facility.

\section{Method}

The method used was an applied research focused on an existing problem requiring immediate attention [34]. The project was undertaken from a social science perspective with an understanding that the variables of interest were complex and could not be subjected to a positivist experimental research approach. The WHO healthy workplace model recommended observation method for assessment of the physical work environment; while, survey or interview was suggested for the remaining three avenues of influence [33]. Hence, a survey approach was adopted for the study. An exploratory research design was adopted with a mixed method sequential exploratory strategy for the data collection. It began with the qualitative approach for explorative purposes, followed up with a quantitative survey [35]. Pre-determined and emerging methods of data collection were applied using both open and closed ended questions [35].

\subsection{Study Setting}

The Federal Medical Centre, Owerri (FMCO) is one of the federal tertiary health care facilities located in south eastern part of Nigeria [32]. The motto expected to guide activities in the facility is: "Dedicated to Care and Service" [32:12].

\subsection{Study Population}

All nurses working in the employment of the Federal Medical Centre, Owerri constituted the study population. The study was limited to professional nurses because of the specific charge to Get the nurses to go back to work. The nurses were under the Nursing Services Department (NSD) of the hospital. The department had forty-two operating units spread across the various clinical specialty areas, including 
two outreach centres outside the main hospital. As at June 2016, there were 715 nurses serving in the forty-two nursing units. Table 1 shows the distribution of the nurses according to their ranks.

Table 1. Distribution of nurses in the hospital according to rank.

\begin{tabular}{ll}
\hline Older / Senior Nurses & Number in Rank \\
\hline Chief Nursing Officer (CNO) & 71 \\
Assistant Chief Nursing Officer (ACNO) & 51 \\
Principal Nursing Officer & 41 \\
Sub-Total & $163(22.8 \%)$ \\
Younger / Junior Nurses & \\
Senior Nursing Officer (SNO) & 120 \\
Nursing Officer I (NOI) & 123 \\
Nursing Officer II (NOII) & 309 \\
Sub-Total & $552(77.2 \%)$ \\
Grand Total & $715(100 \%)$ \\
\hline
\end{tabular}

\subsection{Qualitative Phase}

One hundred and thirty-nine (139) nurses participated in the qualitative phase of the study. Sampling was purposeful [36], flexible and realistic in methodology, considering individual and contextual characteristics that had implication for the study [37]. Variations and similarities among the nurses were considered, to increase representativeness and confidence [38]. Polit and Beck [34] suggested Focus Group Discussion (FGD) group size of 6-12 discussants and sufficient data collection to saturation level. Therefore, the 139 nurses consisted of 39 Older / Senior nurses in four groups of 10 members each, except one with 9 members; and 100 Younger / Junior nurses in 10 groups of 10 members each.

\subsubsection{Instrument for Qualitative Data Collection}

A semi-structured discussion guide was developed [39-40] with two parts. The first part contained the purpose, guide on how to conduct the discussion, confidentiality, the contact and signature of BOA. The second part had ten main questions and some prompts, in line with the objectives of the study. The questions were on: causes of the industrial action, stakeholder involvement, and prevention of a reoccurrence. Participants were also requested to provide any other information for the attention of, and to assist the Interim Management Committee.

\subsubsection{Data Collection}

The qualitative data was collected through modified Focus Group Discussions (FGD) on $29^{\text {th }}$ December 2015 at the first meeting of BOA with the nurses in the hospital. Modified Focused Group Discussion (FGD), because of the volatility of the issue at the time, the need to build trust, and to reduce bias as much as possible. There was no audio recording of the discussions. The fourteen group discussions were held simultaneously. Group members appointed their own moderator, secretary and observer who were adequately briefed by BOA. The secretary and observer's reports were submitted in longhand. Furthermore, implied consent was obtained [41] by volunteering to participate. Members in each group were volunteers from each rank and the groups were homogenous according to the nurses' ranks. One hundred and thirty-nine out of the 505 nurses present at the meeting volunteered in their respective ranks and participated in the discussion. Confidentiality was assured.

\subsubsection{Data Analysis}

The discussions lasted for between 15 and 52 minutes with a mean duration of 36.7 minutes. There was no need for transcription. Secretary and observer reports for each group were read for overall initial understanding of the content [42, 43]. Simple content analysis was done [34]. Themes were derived from the objectives and the FGD guide questions. Data matrices [39] were developed manually. Highlighted words, phrases and sentences from each group were retrieved and arranged within the matrices for cross analysis group by group. By this, the similarities and differences between focus groups were easy to identify, and explain [43].

\subsubsection{Trustworthiness - (Validity and Reliability of Qualitative Data)}

Detailed description [44] of the process was presented to enhance transferability. There was no inconsistency as data was collected in all the groups simultaneously, same day, under similar condition. The consistency promoted dependability [34, 45]. For credibility and authenticity, expressions of the participants as derived from the matrices were used to develop the questionnaire for the quantitative data collection $[34,46]$.

\subsection{Quantitative Phase}

Because of the risk of attrition due to annual leave, maternity leave, study leave, days and nights off, all the nurses were involved in the second phase of data collection. All interested nurses on all three shifts, in a randomly selected week of the data collection month, were allowed to participate in the study.

\subsubsection{Instruments}

Findings from analysis of the qualitative data were used to develop a Likert item instrument to which participants indicated how much they agreed or disagreed with each item; from Strongly Disagree, Disagree, Neither Agree nor Disagree, Agree, to Strongly Agree. The 75 Likert items were grouped into 7 categories of between 5 to 16 Likert items each [47]. There was a section for the respondents' suggestions / comments. The instrument also had a preamble conveying the salutation, purpose of the study, implied consent by completing the questionnaire, confidentiality, and researchers' information. There was a section for the questionnaire number, participant's service unit, age last birthday in years, and length of service in the hospital. Gender was omitted because the hospital had only 21 male nurses and could be linked to the units.

\subsubsection{Validity and Reliability}

Because the items were customized [35] to the hospital, the instrument was pre-tested with 10 senior and junior 
nurses in one of the units of the hospital. Repetitions and typographical errors were corrected. The reliability of the questionnaire was tested using the Cronbach's alpha coefficient [47] with an acceptable score of $>0.9$.

\subsubsection{Data Collection}

The instrument was ready in June 2016; hence, the decision to collect the data in July. Week Monday $18^{\text {th }}-$ Friday, $22^{\text {nd }}$ in July, 2016 was randomly selected for data collection. The instrument was self-administered. Four hundred and seventy-nine nurses participated in this phase of the study from all the units except the unit that was involved in pre-testing of the instrument.

\subsubsection{Data Analysis}

Epi Info ${ }^{\text {TM }} 7$ version 3 3/21/2016 statistical package for public health professionals was used for data entry and analysis. Frequencies, percentages and mode were calculated for all the items [48], and Chi-square was calculated between the senior and junior nurses' responses.

\subsection{Ethical Consideration}

Ethical Approval to conduct the study was granted by the Ethical Committee of the Federal Medical Centre Owerri vide $\mathrm{FMC} / \mathrm{OW} / \mathrm{HREC} / 123$. All the participants were provided with adequate information on the purpose of the study. Personal contact details of BOA and open access were provided to all nurses in the hospital. Confidentiality was ensured throughout the study and afterwards.

\section{Results}

\subsection{Description of the Respondents}

Out of the 479 instruments retrieved from the participants, $461(96.2 \%)$ were found duly completed and useable. Distribution of the nurses by rank and length of service is presented in Table 2. The oldest nurse was aged 59 years and the youngest 25 years; the mean age was 39.22 years and the mode, 40 years.

Table 2. Distribution of participants by rank and length of service.

\begin{tabular}{llll}
\hline \multirow{2}{*}{ Grouped Ranks } & \multicolumn{2}{l}{ Length of Service in Years } & \multirow{2}{*}{ Total } \\
\cline { 2 - 4 } & $\mathbf{1 0}$ years and below & $\mathbf{1 1}$ years and above & $124(26.90 \%)$ \\
\hline CNOs, ACNOs \& PNOs (Senior Nurses) & $11(8.87 \%)$ & $113(91.13 \%)$ & $337(73.10 \%)$ \\
SNOs, NOIs \& NOIIs (Junior Nurses) & $321(95.25 \%)$ & $16(4.75 \%)$ & $461(100 \%)$ \\
Total & $332(72.02 \%)$ & $129(27.98 \%)$ & \\
\hline
\end{tabular}

\subsection{Causes of the 2015 Protracted Industrial Action in the Hospital}

Table 3 shows opinion of the nurses on causes of the industrial action; arranged from the cause with the highest frequency to the lowest.

Table 3. Nurses'opinion on the causes of 2015 protracted industrial action (in descending order).

\begin{tabular}{|c|c|c|c|c|c|c|}
\hline SN & $\begin{array}{l}\text { Causes of the } 2015 \text { protracted industrial action in the } \\
\text { hospital }\end{array}$ & $\begin{array}{l}\text { Strongly Disagree } \\
\text { \& Disagree }(\%)\end{array}$ & $\begin{array}{l}\text { Neither Agree nor } \\
\text { Disagree (\%) }\end{array}$ & $\begin{array}{l}\text { Agree \& Strongly } \\
\text { Agree }(\%)\end{array}$ & $\begin{array}{l}\text { Chi sq. } \\
\text { value }\end{array}$ & p-value \\
\hline 1 & $\begin{array}{l}\text { Disparity in salary of nurses in the hospital and nurses in } \\
\text { similar hospitals }\end{array}$ & $7(1.52)$ & $11(2.39)$ & $443(96.10)$ & 1.46 & 0.482 \\
\hline 2 & Highhandedness (intimidation and victimization) & $9(1.95)$ & $16(3.47)$ & $436(94.58)$ & 0.736 & 0.692 \\
\hline 3 & Backdating of appointment without arrears & $9(1.95)$ & $26(5.64)$ & $426(92.41)$ & 1.69 & 0.430 \\
\hline 4 & Non-payment of arrears / allowances & $3(0.65)$ & $33(7.16)$ & $425(92.19)$ & 0.187 & 0.911 \\
\hline 5 & Denial of opportunity for training & $17(3.68)$ & $21(4.56)$ & $423(91.76)$ & 5.22 & 0.074 \\
\hline 7 & Irregular payment of salaries and emoluments (errors on IPPIS) & $24(5.21)$ & $24(5.21)$ & 413(89.59) & 0.522 & 0.770 \\
\hline 8 & Due Process not followed for PPP & $11(2.39)$ & $42(9.11)$ & $408(88.5)$ & 0.692 & 0.707 \\
\hline 9 & No free and fair treatment among nurses especially superiors & $28(6.08)$ & $30(6.51)$ & $403(87.42)$ & 2.02 & 0.364 \\
\hline 10 & Lack of incentive / motivation & $9(1.95)$ & $57(12.36)$ & $395(85.69)$ & 3.94 & 0.140 \\
\hline 11 & Lack of job security & $23(4.99)$ & $48(10.41)$ & $390(84.60)$ & 1.11 & 0.573 \\
\hline 12 & Disregard for seniority in appointment into positions & $28(6.07)$ & $45(9.76)$ & $388(84.17)$ & 1.52 & 0.469 \\
\hline 13 & Nepotism (favouring relatives and friends) & $30(6.50)$ & $47(10.20)$ & $384(83.29)$ & 0.854 & 0.653 \\
\hline 16 & Employment racketeering & $23(4.99)$ & $82(17.79)$ & $356(77.22)$ & 2.81 & 0.245 \\
\hline
\end{tabular}

Review of the qualitative data on Disparity in salary of nurses in the hospital and nurses in similar hospitals, which is the first cause of the crisis as shown in Table 3 , revealed that the nurses compared themselves with their colleagues in similar institutions in terms of placement on salary grade level at appointment and after promotion, as well as payment of some allowances like teaching and call duty allowances. Highhandedness, the second highest cause of the crisis was reportedly related to incidences of intimidation and victimization by the Medical Director in-charge of the hospital. The unpaid Arrears included: promotion, relativity, and skipping arrears; while, the unpaid Allowances indicated by the nurses included: rural, teaching, uniform and course allowances. Concerning the Denial of opportunity for training, nurses remarked that for more than five years they were not allowed to go for further studies and were not 
supported for professional development activities. Nurses who ventured to do part time programmes were fished out and directed to terminate such programmes or face disciplinary actions. Stagnation of CNOs and other nurses was one of the first ten causes of the crisis. According to the qualitative reports, the last promotion of nurses to the Assistant Director (AD) level was in 2010 in spite of the fact that there were qualified and "promotion matured" nurses. With the exit of the last AD by statutory retirement, the most senior nurse in the hospital was a Chief Nursing Officer; whereas, other clinical departments were headed by Directors, Deputy Directors, or at least an Assistant Director or their equivalents. Nurses therefore constituted the only core health professional group in the hospital without a Head in the directorate cadre. There were at least eighteen Assistant Director (AD) positions which needed to be filled as at the time of the industrial action in 2015. There were complaints from some nurses on the Irregular payment of salaries and emoluments (errors on IPPIS). Some had 1-6 months salaries unpaid (skipped for no reason) in 2014 and 2015 despite repeated complaints to the Accounts Department of the hospital, and promises that the errors would be corrected. Some felt victimized. The nurses indicated that Due Process was not followed for PPP (Public Private Partnership) programme proposed by the Medical Director and, similar ventures in the past had nothing positive to show for their existence. The Lack of incentive / motivation referred to denial of call food to nurses on call and lack of call rooms for deserving nurses; while, other perioperative workers were adequately catered for. Nurses reported instances when it was announced in the suite that they were not entitled to such privileges. This was demoralizing and provoking. The Chi-square suggested a difference in the responses of the senior and junior nurses only on the Financial Misappropriation by Management (senior nurses 93(75\%) and junior nurses 264(78.34\%) pvalue 0.025 ).

\subsection{Why the Hospital Was Shut Down}

The nurses opined that the hospital was shut down because the investigation panel did not present the facts found (369(80.05\%), the crisis was serious (341(73.97\%), and because the workers preferred the outright removal of the MD, to the Minister of Health's option of bringing back the MD who had been asked to step aside (334(72.45\%). Less than half of the nurses felt the shutdown was to re-organize the hospital $(206(44.69 \%)$ or to redefine the terms of engagement of staff (157(33.97\%).

\subsection{Parties Involved in the 2015 Protracted Hospital Crisis}

The people or groups identified as being involved in the crisis were the staff (422(91.54\%), the Medical Director (407(88.29\%), the Hospital Management (397(86.12\%), the Minister of Health $(377(81.78 \%)$, The Ministry of Health
(374(81.13\%), the Panel of enquiry (356(77.22), the Federal Government (326(70.71\%), and the Acting Medical Director (306(66.38\%).

\subsection{What Should Not Have Been Done by the Involved Parties}

Majority of the nurses believed that the Federal Government and the Ministry of Health should not have delayed intervention (442(95.88\%), should not have failed in their promise to investigate the crisis $(430(93.27 \%)$, should not have harassed the workers or called them names $(397(86.12 \%)$, should not have shut down the hospital (383(83.08\%), and should not have allowed the 2015 election to distract them or cause delay in intervening in the crisis (339(73.53\%). Furthermore, the nurses indicated that the Medical Director (MD) should not have rejected the Board resolution for her to step aside (437(94.8) and should not have taken over forcefully from the Acting MD (432(93.71) who was appointed to temporarily hold the office. Similarly, the hospital's Management Committee members should not have refused to go on one month leave as advised by the Board (404(87.63). The Panel of Enquiry should not have tailored the report to favour the MD (428(92.85) and should not have tampered with facts (426(92.41). The Acting Medical Director should not have handed over to the MD under duress (391(84.81). Only 44 (9.54\%) nurses opined that the staff should not have worn black attire during the protest and $92(19.96 \%)$ indicated that the staff should not have refused to dialogue with some mediating groups.

Table 4. What the involved parties should have done (in descending order).

\begin{tabular}{|c|c|c|}
\hline $\mathbf{S N}$ & $\begin{array}{l}\text { What should have been done by the parties } \\
\text { involved }\end{array}$ & $\begin{array}{l}\text { Agree / Strongly } \\
\text { Agree (\%) }\end{array}$ \\
\hline 1 & Early intervention by Government & $449(97.39)$ \\
\hline 2 & $\begin{array}{l}\text { Management ensuring healthy relationship } \\
\text { with the staff }\end{array}$ & $446(96.74)$ \\
\hline 3 & $\begin{array}{l}\text { Government not politicizing workers' } \\
\text { grievances }\end{array}$ & $442(95.88)$ \\
\hline 4 & $\begin{array}{l}\text { Government paying workers' outstanding } \\
\text { entitlements }\end{array}$ & $439(95.22)$ \\
\hline & Management applying the Public Service & \\
\hline 5 & $\begin{array}{l}\text { Rules to the letter in running the affairs of the } \\
\text { hospital }\end{array}$ & 434(94.14) \\
\hline 6 & $\begin{array}{l}\text { All the Parties involved engaging in early and } \\
\text { peaceful dialogue }\end{array}$ & $429(93.06)$ \\
\hline 7 & $\begin{array}{l}\text { Top Management Committee members } \\
\text { adhering to Board's directive }\end{array}$ & $427(92.62)$ \\
\hline 8 & Panel of enquiry shunning compromise & 425(92.19) \\
\hline 9 & $\begin{array}{l}\text { Provision of structurally good working } \\
\text { environment by Management }\end{array}$ & 423(91.76) \\
\hline 10 & $\begin{array}{l}\text { Management liaising with House Unions on } \\
\text { PPP before going on air }\end{array}$ & $422(91.54)$ \\
\hline 11 & $\begin{array}{l}\text { Provision of adequate instruments and } \\
\text { equipment by Management }\end{array}$ & $418(90.68)$ \\
\hline 12 & $\begin{array}{l}\text { Minister sending a Sole Administrator instead } \\
\text { of the shut down }\end{array}$ & $416(90.24)$ \\
\hline
\end{tabular}


Table 5. How reoccurrence of the industrial action can be prevented (in descending order).

\begin{tabular}{|c|c|c|c|c|}
\hline SN & The industrial action will not occur again if: & $\begin{array}{l}\text { Strongly Disagree } \\
\text { / Disagree }(\%)\end{array}$ & $\begin{array}{l}\text { Neither Agree nor } \\
\text { Disagree }(\%)\end{array}$ & $\begin{array}{l}\text { Agree / Strongly } \\
\text { Agree (\%) }\end{array}$ \\
\hline 1 & Communication between Management and workers is effective & $2(0.43)$ & $9(1.95)$ & $450(97.61)$ \\
\hline 2 & Workers are promoted as and when due & $7(1.51$ & $7(1.51)$ & $447(96.96)$ \\
\hline 3 & $\begin{array}{l}\text { There is harmonization of salaries of the staff with those of workers in other federal } \\
\text { tertiary health institutions }\end{array}$ & $6(1.3)$ & $10(2.17)$ & $445(96.53)$ \\
\hline 4 & The MD does not come back to head the hospital & $5(1.09$ & $14(3.04)$ & $442(95.87)$ \\
\hline 5 & Nurses are properly placed on salary scales & $9(1.95)$ & $12(2.60)$ & $440(95.44)$ \\
\hline 6 & Management uses the Public Service Rules in disciplining erring workers & $7(1.52)$ & $15(3.25)$ & $439(95.23)$ \\
\hline 7 & all the benefits / arrears owed workers are paid & $16(3.47)$ & $7(1.52)$ & $438(95.01)$ \\
\hline 8 & Management avoids highhandedness & $5(1.08)$ & $18(3.90)$ & $438(94.99)$ \\
\hline 9 & $\begin{array}{l}\text { Management is proactive not waiting for workers to complain before taking } \\
\text { necessary actions }\end{array}$ & $10(2.17)$ & $17(3.69)$ & $434(94.15)$ \\
\hline 10 & Management encourages in-service training, seminars and workshops & $10(2.15)$ & $18(3.90)$ & 433(93.93) \\
\hline 11 & $\begin{array}{l}\text { Management does not say PPP is because the workers are not productive, not } \\
\text { efficient or not effective }\end{array}$ & $15(3.25)$ & $26(5.64)$ & $420(91.10)$ \\
\hline 12 & Various academic degrees relevant to nursing profession are encouraged & $14(3.04)$ & $32(6.94)$ & $415(90.03)$ \\
\hline 13 & There is provision of materials to work with in the hospital & $21(4.55)$ & $34(7.38)$ & $406(88.07)$ \\
\hline 14 & $\begin{array}{l}\text { Nurses do not have another HOD like the last HOD to head Nursing Department } \\
\text { again }\end{array}$ & $24(5.21)$ & $34(7.38)$ & 403(87.42) \\
\hline 15 & Management involves workers in the running of the hospital & $20(4.34)$ & $45(9.76)$ & $396(85.90)$ \\
\hline
\end{tabular}

Table 6. How to prevent reoccurrence of the shutdown of the hospital by Government (in descending order).

\begin{tabular}{|c|c|c|c|c|}
\hline SN & The hospital will not be shut down again if: & $\begin{array}{l}\text { Strongly Disagree / } \\
\text { Disagree }(\%)\end{array}$ & $\begin{array}{l}\text { Neither Agree nor } \\
\text { Disagree }(\%)\end{array}$ & $\begin{array}{l}\text { Agree / Strongly } \\
\text { Agree (\%) }\end{array}$ \\
\hline 1 & Panels of enquiry give accurate reports & $2(0.44)$ & $11(2.39)$ & $448(97.18)$ \\
\hline 2 & Prompt and appropriate solution to the causes of the industrial action & $4(0.86)$ & $10(2.17)$ & $447(96.96)$ \\
\hline 3 & Proper communication / dialogue & $2(0.44)$ & $12(2.60)$ & $447(96.96)$ \\
\hline 4 & Government / Federal Ministry of Health is not sentimental but base decisions on facts & $2(0.44)$ & $13(2.82)$ & $446(96.75)$ \\
\hline 5 & Efforts are made to maintain peace and harmony in the hospital & $4(0.86)$ & $15(3.25)$ & $442(95.88)$ \\
\hline
\end{tabular}

\section{Discussion}

\subsection{Causes of Industrial Actions}

All the sixteen causes of the 2015 strikes identified by the nurses (Table 3) fell within the psychosocial environment of the WHO healthy workplace framework. The Psychosocial Work Environment includes the organization of work and the organizational culture; the attitudes, values, beliefs and practices that are demonstrated on a daily basis in the enterprise / organization, and which affect the mental and physical well-being of employees [33].

The causes reported by the nurses were in line with findings in previous studies presented in the introduction. Similarly, resident doctors in the hospital whose perspective of the strike was examined at the same time this study was carried out, indicated the causes of industrial crisis in the hospital as administrative lapses, poor welfare packages, lack of sponsorship for training, and delayed payment of salaries [3]. However, the lack of job security reported by the nurses was not related to mergers, acquisitions, reorganizations, or the labour market / economy as opined by Burton [33]; rather, it was related to highhandedness and victimization.

\subsection{Why the Hospital Was Shut Down}

The eventual shut down of the hospital was largely attributed to the inability of the investigation panel to present an unbiased report. Expectedly, the panel was appropriately constituted with representatives of both the government and workers' unions as members. However, because corruption is a cause of industrial crisis [23], it is essential for such government panels to be both responsible and truthful [25]. The shutdown was also considered to be due to the seriousness of the crisis; more so, when the position of the Minister was not acceptable to the workers, and, none of the mediating traditional and government representatives could prevail on the workers to suspend their strike. Interventions should be based on unbiased assessment of the situation that led to the industrial action; and, arbiters must not be seen or suspected to be biased.

\subsection{The Involved Parties}

In identifying the parties involved in the industrial crisis, the nurses listed the federal government, her agencies and their representatives (panel of enquiry and the Minister), separately. Similarly, in the hospital, the Management of the hospital and the Medical Director were identified separately, as well as the members of staff. This suggests recognition of difference between the office of those in positions of authority as government representatives, and, their personal actions. Rules and regulations guide operations in offices; however, human beings and workplace circumstances are not always the same, hence, the importance of individual skills and attributes in management. 


\subsection{What Involved Parties Should Not Have Done}

Delayed intervention is not advisable during industrial crisis; particularly, in health sector crisis. Crisis managers should be appropriately trained to be proactive [28]. Furthermore, failure of government to keep her promises that was disapproved by the nurses, was reported by Gyamfi [20] as one of the causes of industrial crisis. Name calling and blame game reported, was indicated as a post crisis feature in Smith's model [49], and has the risk of worsening the situation [9]. Although the Boards of health parastatals represent the Minister (government), their power over the chief executives is limited [50]; little surprise therefore, that the intervention of the Board in the crisis was ineffective. Prompt and definite intervention by the supervising ministry and government is therefore critical.

Reaction of the workers to alleged false report by the investigation panel worsened the crisis and was identified as being responsible for the shutdown. Untrue report has the potential to misdirect intervention towards ineffective outcome. As discussed earlier, character of individual leader varies and plays out in times of crisis. This could have accounted for the Acting Medical Director's response under pressure. Survival, is a fundamental need and would naturally be attended to first before higher order needs; hence, the acting chief executive's choice of handing over than holding on to the position when threatened.

Contrary to the opinion of government that black uniform was occultic, majority of the nurses saw nothing wrong with the workers wearing black uniform during the protest. Considering Smith's model, making issue out of the protesters' attire, is part of the crisis of legitimization phase during which efforts are made by parties to restore external confidence. Issues critical to resolution of crisis should be the focus of intervention and not distracting elements like attire worn by protesters; such distractions could engender prejudice. Only one-fifth of the nurses opined that staff should not have refused to dialogue with some mediators. Workers are a part of the community in which they work and identify with the sociocultural climate of the environment. Respect for socio-political leaders, including traditional rulers, is part of Nigerian culture. Aggrieved workers' refusal of intervention by such people could be capitalized upon by government to push her crisis legitimization [49] agenda and pitch the workers against the public, who no longer enjoyed access to health services. Dialogue remains a key strategy in crisis intervention. Oleribe et al. [18], documented poor health care leadership and management as the commonest and most important cause of industrial action in Nigerian health sector. Therefore, every mediator, no matter how highly placed, or the relationship he / she has with leaders of the organization, must be objective about the facts of the crisis, and should not take sides. A workers' union, though made up of people, is considered powerful and greater than individual members. It is subject to labour laws and does not respond to socio-political and traditional sentiments; unless, as a strategy to pave way for peaceful resolution, and not prejudice.

\subsection{What Involved Parties Should Have Done}

What the involved parties should have done could be classified into two categories, relating to the pre- and intracrisis culture and disposition, of the organization and the workers [49]. Pre crisis, employers should be proactive, knowing that crisis is possible even when there is no obvious threat [7]; and put workable policies in place to avoid strike actions and their consequences [23]. Findings from the study show that, it is important that a healthy relationship is created and promoted between the management and the members of staff. Collaboration between the management and staff is a feature of a healthy workplace [33]. Management plans and decisions should be discussed with the workers, and not heard first by workers outside the organization or through the social media. In view of the fact that salary related issues feature in many industrial crises, government should agree to what is doable and keep to the terms of agreement. Where implementation is problematic, workers should be appropriately informed [3], and more importantly, they must be part of every arrangement for a speedy resolution of the problem.

Anarchy is usually the result of noncompliance to extant regulations. The Public Service Rules (PSR) should be applied in all government establishments. to prevent victimization, nepotism and abuse of "power". Poverty increases vulnerability [51]. The high rate of unemployment and poverty in the country increases desperation of workers to keep whatever means of livelihood is available to them even when administrators disregard the provisions of the PSR and enforce personal rules, causing fear and sense of job insecurity among workers. Noncompliance with the provisions of the PSR, promotes highhandedness, victimization, and nepotism as indicated in this study, leading to industrial disharmony. If the Boards represent the parent ministry at the facility level, they should be adequately empowered to take important decisions binding on members of staff at the highest management level in the facility; particularly during crisis. Otherwise, in view of the usual bureaucratic processes, the government, Boards and management must devise strategies for quick intervention to ensure peace and order.

Although the nurses did not include factors in the physical work environment as causes of the industrial action, these were identified as things that stakeholders should have attended to prior to the industrial crisis. Such as, provision of adequate instruments and equipment, as well as structurally good working environment.

\subsection{How to Prevent Reoccurrence of the Strike Action and Shutdown of the Hospital: Application of Who Healthy Workplace Model}

Considering the grave consequences suffered by the public in 2015 and 2016, a critical part of this project was suggesting strategies to prevent reoccurrence of the industrial action and shutdown of the hospital. The hierarchy of control of workplace hazards described by Burton [33], is to 
eliminate the hazard if possible or modify the hazard at the source; lessen the impact of the hazard on the worker; or help the worker protect him or herself from effects of the hazard. The identified causes of the strike action and shutdown of the facility could be considered as the hazards. Applying Burton's [33] hierarchy implies that some of the causes must be eliminated, some modified, and the workers would need to be prepared to adapt to some which cannot be eliminated or modified.

\subsubsection{Elimination of the Hazard or Modifying It at Source}

This strategy, according to Burton [33], could involve removing the manager, or retraining the managers / supervisors in communication and leadership skills; enforcing zero tolerance for harassment, bullying or discrimination in the workplace; applying all legal standards and laws regarding workplace conditions or putting policies in place to supplement the laws [33]. These activities are in line with some of the suggestions of the workers; such as, removal of the $\mathrm{MD}$, not having another nurse leader with the unacceptable character of the former, and avoidance of highhandedness. Oleribe et al. [18] reported poor health care leadership and management as the commonest and most important cause of industrial action in Nigerian health sector; yet, the government is usually reluctant to replace such managers. In the facility under study, the reinstatement of the MD after an initial stay away order led to further crisis and uneasy calm in the facility until an acting MD and eventually a substantive MD was appointed. Government needs to be more objective, fearless, and trustworthy [25].

Strictly applying all legal standards and laws regarding workplace conditions [33], as contained in the public service rules, financial regulations, and government circulars, could "modify the hazard at source", and prevent reoccurrence of the industrial crisis. Some issues identified by the nurses for attention in order to prevent reoccurrence had been adequately provided for in the government documents. These are related to promotions, placement on salary at appointment and after upward movement, allowances and other entitlements, and support for maximum professional development activities. These are implementable government policies guiding activities in the public service [16, 23]. Provisions of the regulations are binding; and problems arising therefrom must be promptly discussed and resolved to avert crisis [3]. Sequel to the evidence-based reports of the Interim Management Committee, confirming some of the "hazards" reported by the nurses, promotion exercises were conducted, and workers released for seminars, and in-service training programmes. Percentages of outstanding allowances that could not be fully paid were agreed upon by management and workers, and were settled accordingly. This could have been done ab initio and the crisis prevented.

\subsubsection{Lessen the Impact of the Hazard on the Worker}

Provision of structurally good working environment and adequate equipment was one of the expectations of the nurses before the crisis. The weak state of the nation's health system, with poor infrastructure, grossly inadequate human and material resources, and poor management of human resources among others, is acknowledged by the government [52]. The system is generally not enabling; as such, it does not encourage efficient performance by the workers [2, 29]. This obvious impact of the poor health system on the workers' performance requires that the government should do everything possible to improve the workplace environment steadily; even if slowly. Government should ensure that equipment purchased are of good quality, useable, and not just locked up; while, the supposed end users suffer. Every stakeholder must be part of the developmental activities. The rate of exit of nurses from the facility for various reasons was quite high; however, the created vacancies were not adequately filled leading to gross shortage of nurses. Poor staffing has been associated with nurses' dissatisfaction, burnout, and poor quality of nursing care [53]. Replacement of exited staff does not increase government spending; hence, the need for a standing personnel replacement policy to reduce personnel dissatisfaction which is one of the promoters of industrial crisis.

\subsubsection{Help the Worker Protect Him or Herself from Effects of the Hazard}

According to Burton [33], this healthy workplace strategy involves raising the awareness of workers and training them on issues such as stress management. Apart from the fact that some nurses who were matured / qualified for promotion were stagnated, there were others who were waiting for promotion, not knowing they could not be promoted to the directorate level because the nature of the first degree they had was not acceptable. They lacked adequate information about the deficiency, and the provisions by the regulatory agency and tertiary institutions in the country on how to resolve the problem. Knowledge strengthens and lightens hope; thus, protective against mental and emotional stress that could aggravate crisis. Interestingly, as soon as the necessary information was provided and due resource linking effected, the affected nurses seized the opportunity to do the needful.

Part of the protection strategy is helping nurses to balance demands of professional responsibility to consumers and the exercise of their rights to industrial action. Although the "no work, no pay" rule is usually not enforced during strike actions, studies have shown that many workers do not want to participate; not all workers support strike actions [18], because of the rationale [19], and obvious consequences; including, irredeemable loss of lives [26]. As spiritual and emotional beings, grave consequences of strike actions make some nurses want to boycott strikes; but they are usually coerced into participating. There is need for training on promoting industrial harmony [33], and bearing the consequences of illegal strike actions. Such consequences may include loss of pay by employers, though the organized labour unions may choose to pay for the days workers are pulled out of work [5, 6, 17].

\subsection{Implication for Nursing Services at FMC Owerri}

In view of the charge to "Get the nurses to go back to 
work", after the first phase of data collection, there was active engagement of the nurse managers in activities to lessen the impact of the strike and protect the nurses. Burton [33] emphasized the importance of knowledge transfer and components of action research in the process of creating a healthy workplace; hence, the utilization of the preliminary findings of the qualitative phase of the study in starting off some of the intervention measures reported in this study and their outcomes. It is expected that, having participated in the positive process of change, the nurse managers would see themselves as stakeholders, and would be able to confidently and effectively participate in management of the facility without fear of victimization.

\section{Conclusion}

Industrial actions in the health sector deny the public their right to quality health care and protection from avoidable death. Expecting that aggrieved workers can be coerced to suspend strike and go back to work without effective intervention from stakeholders is fantasy. The WHO model of healthy workplace is recommended for all parties involved in workplace crisis resolution, as a guide to situation analysis and appropriate intervention. All hands must be on deck to prevent strikes by promoting healthy workplaces in the health sector.

\section{Acknowledgements}

The FGD guide was reviewed by $\mathrm{Mr} \mathrm{Abdu}$ Ibrahim Msheliza, the pharmacist on the Interim Management Committee (IMC) at the Federal Medical Centre, Owerri.

\section{References}

[1] Ige K, Adeyeye F, Aina S. An empirical study of the factors influencing Industrial Conflicts in Nigeria (1980-2010). European Journal of Humanities and Social Sciences. 2011; 10 (1(Special Issue)): 423-39.

[2] Seniwoliba AJ. Ghana's numerous workers strikes; a cause for concern. Merit Research Journal of Education and Review. 2013; 1 (8): 159-71.

[3] Okonta KE, Okonta OC. Industrial crises in a Tertiary Health Institution (THI) in Nigeria: The perspective of resident doctors. International Journal of Healthcare Management. 2017.

[4] National Ethics Advisory Committee. The Ethical Principle of 'Do No Harm' and Industrial Action. Wellington New Zealand: Ministry of Health; 2013.

[5] International Organisation of Employers. Findings of IOE Member Country Survey on the Right to Strike: IOE; 2015.

[6] Ekpo H. Nigeria: 'Relevance of No Work, No Pay Rule in Curbing Labour Unrest in Public Sector'. Abuja: Guardian Newspapers; 2016 [cited 2017 6th January]; 13th September, 2016: [Online Newspaper]. Available from: http://allafrica.com/stories/201609130671.html.
[7] Zech N. Stakeholder Relationship Management in the Context of Crisis Management. New Challenges of Economic and Business Development. 2013; May 9 - 11, 2013, Riga, University of Latvia: 681-92.

[8] Jaques T. Reshaping crisis management: the challenge for organizational design. Organizational Development Journal. 2010; 28 (1): 9-17.

[9] Haiven L, Haiven J. The Right to Strike and the Provision of Emergency Services in Canadian Health Care. Ottawa: Canadian Centre for Policy Alternatives, 410-75 Albert Street, Ottawa, ON K1P 5E7; 2002.

[10] Dhai A, Etheredge HR, Vorster M, Veriava Y. The public's attitude towards strike action by healthcare workers and health services in South Africa. SAJBL. 2011; 4 (2): 58-62.

[11] Nursing \& Midwifery Council of Nigeria. Code of Professional Conduct. Abuja: Nursing \& Midwifery Council of Nigeria; 2016 [cited 2017 27th January,]; Available from: http://www.nmcn.gov.ng/codec2.html.

[12] Ogundipe S, Obinna C, Olawale G. Shortage of medical personnel: Tougher times ahead for Nigerians Vanguard. 2015.

[13] Rosseter R. The American Association of Colleges of Nursing - Nursing Fact Sheet. The American Association of Colleges of Nursing 2011 [updated April 12, 2011; cited 2017 24th January]; Available from: http://www.aacn.nche.edu/mediarelations/fact-sheets/nursing-fact-sheet.

[14] Asuquo EF, Etowa J, John M, Ndiok A, Sampson-Akpan P, Edet O. Assessing Nurses' Capacity for Health Research and Policy Engagement in Nigeria. Journal of Applied Medical Sciences. 2013; 2 (4): 35-51.

[15] NLC. Nigeria Labour Congress - International Policy and Affiliations Abuja: Nigeria labour Congress; 2017 [cited 2017 6th January]; Available from: http://www.nleng.org/.

[16] Osakede KO, Ijimakinwa SA. The Effect of Public Sector Health Care Workers Strike: Nigeria Experience Review of Public Administration and Management. 2014; 3 (6): 154-61.

[17] DLA Piper. Best Practice Guide to Industrial Action. Australia: DLA Piper; 2013.

[18] Oleribe OO, Ezieme IP, Oladipo O, Akinola EP, Udofia D, Taylor-Robinson SD. Industrial action by healthcare workers in Nigeria in 2013-2015: an inquiry into causes, consequences and control-a cross-sectional descriptive study. Human Resources for Health. 2016; 14 (46): 1-10.

[19] Nala NP. Strategies for Curbing Strike Action by Nurses in Public Institutions, South Africa: University of South Africa; 2014.

[20] Gyamfi GD. Assessing the effects of industrial unrest on Ghana health service: A case study of nurses at Korle-Bu teaching hospital. International Journal of Nursing and Midwifery. [Original Research]. 2011; 3 (1): 1-5.

[21] Commonwealth Trade Union Group. 2007 Annual survey of violations of trade union rights in the Commonwealth countries: ITUC CSSI IGB; 2007.

[22] Isiaka SA. The Continued Relevance of Strike as a Form of Industrial Action in Nigeria. HUMANITY Jos Journal of General Studies 2001; 3 (2): 36-44. 
[23] Ukonu IO, Emerole GA. The Role of National Industrial Court in Sustaining Harmony in Nigerian Health Sector: A Case of University of Abuja Teaching Hospital. Journal of Management and Sustainability. 2016; 6 (1): 171-81.

[24] Ankomah M. Rampart Strike Actions in the Public Health Sector: Curbing the Menace. Martin Ankomah (Administrator, HRD, GHS); 2009 [cited 2017 25th January]; 1-8]. Available from: http://ahsag.org/pressreleases/Martin-\%2029.pdf

[25] Nigeria Health Watch Admin. How strikes are killing the Public Healthcare Sector and why it may be difficult to reclaim Africa Health Nigeria; 2015 [cited 2017 25th January,]; Available from: http://nigeriahealthwatch.com/howstrikes-are-killing-the-public-healthcare-sector-and-why-itmay-be-difficult-to-reclaim/.

[26] National Bureau of Statistics. Economic Cost of the Nationwide Strike Action of 9th January - 16th January, 2012: Initial Assessment 2012.

[27] Odhong E, Were S, Omolo J, editors. Re-thinking Industrial Relations for Enhanced Organizational Performance in Kenya. International Conference on Sustainable Research and Innovation 7th - 9th May 2014; 2014.

[28] Efstathiou P, Papafragkaki D, Gogosis K, Manwlidou Z. Crisis management in the Health Sector; Qualities and characteristics of health crisis managers. International Journal of Caring Sciences. 2009; 2 (3): 105-7.

[29] WHO. Public Services International (PSI) Terms of Employment and Working Conditions in Health Sector Reforms Points for DiscussionS. Workshop on Global Health Workforce Strategy; Annecy, France, 9-12 December 20002001.

[30] NLC. Nigeria Labour Congress Policy Document 2007. Available from: https://www.nleng.org/policydoc.pdf on 6th January, 2017.

[31] Kalinde SA. Position on Industrial Actions and Strikes and the Impact on Human Rights. In: Commission MHR, editor.: 29th December, 2014 - MHRC 2014.

[32] IMC. Report of the Interim Management Committee constituted by the Federal Ministry of Health on the Management and Administration at the Federal Medical Centre, Owerri, Imo State. Owerri: Federal Medical Centre 2016 June, 2016.

[33] Burton J. WHO Healthy Workplace Framework and Model: Background and Supporting Literature and Practices. Geneva, Switzerland: World Health Organization; 2010.

[34] Polit DF, Beck CT. Nursing Research: Generating and Assessing Evidence for Nursing Practice 8th Edition. Philadelphia: Wolters Kluwer / Lippincott Williams \& Wilkins; 2008.

[35] Creswell JW. Research Design: Qualitative, Quantitative, and Mixed Methods Approaches. 3rd ed. California: SAGE Publications, Inc.; 2009.

[36] Byrne M. Sampling for qualitative research. AORN Journal. 2001:

http://findarticles.com/p/articles/mi_m0FSL/is_2_73/ai_70871 $448 /$

[37] Marshall MN. Sampling for qualitative research. Family Practice. 1996;Vol. 13 (6): 522-5.
[38] Miles MB, Huberman AM. An Expanded Sourcebook Qualitative Data Analysis 2nd ed. London: SAGE Publications International Educational and Professional Publisher; 1994.

[39] Amin S, Das J, Goldstein M, (Edrs.). Are you being served? New Tools for Measuring Service Delivery. Washington DC The International Bank for Reconstruction and Development / The World Bank; 2008.

[40] Debus M. Methodological Review A Handbook for Excellence in Focus Group Research. Washington, D.C: Academy For Educational Development HEALTHCOM; 2005.

[41] Emanuel JE, Wendler D, Killen J, Grady C. What Makes Clinical Research In Developing Countries Ethical? The Benchmarks of Ethical Research. JID. 2004; 189 (1 March): 930-7.

[42] Bradley EH, Curry AL, Devers KJ. Qualitative data analysis for health services research: developing taxonomy, themes, and theory. Retrieved 19th June 2009 from http://findarticlescom/p/articles/mi_m4149/is_4_42/ai_n27331 528/?tag=content;coll 2007.

[43] Creswell JW, Ebersohn L, Eloff I, Ferreira R, Ivankova NV, Jansen JD, Nieuwenhuis J, Pietersen J, Plano Clark VL, van der Westhuizen C, Kobus ME. First Steps In Research. Pretoria: Van Schaik Publishers; 2008.

[44] Cohen D, Crabtree B. "Qualitative Research Guidelines Project". Lincoln and Guba's Evaluative Criteria 2006:http://www.qualres.org/HomeLinc-3684.html

[45] Trochim WMK. Qualitative Validity. Web Center For Social Research Methods. 2006 10/20/2006:Retrieved 9th April 2009 from http://www.socialresearchmethods.net/kb/qualval.php.

[46] Lincoln YS, Guba EG. Naturalistic Inquiry. Newbury Park, CA: SAGE Publications; 1985.

[47] Brown JD. Likert items and scales of measurement? SHIKEN: JALT Testing \& Evaluation SIG Newsletter. 2011; 15 (1): 104.

[48] Boone HN, Boone DA. Analyzing Likert Data. Journal of Extension. 2012; 50 (2): 1-5.

[49] Smith D. Beyond contingency planning: towards a model of crisis management. Industrial Crisis Quarterly. 1990; 4 (1990): 263-75.

[50] Adetayo O. Boards have no power to suspend CEOs of parastatals, says SGF. Punch [serial on the Internet]. 2018; (October 30, 2018): Available from: https://punchng.com/boards-have-no-power-to-suspend-ceosof-parastatals-says-sgf-2/

[51] NPC. Nigeria Demographic and Health Survey 2013. Abuja, Nigeria: National Population Commission Federal Republic of Nigeria 2014.

[52] FMOH. Federal Republic of Nigeria National Strategic Health Development Plan (National Health Plan) 2010-2015. Abuja, Nigeria: Federal Ministry of Health; 2010.

[53] Aiken LH, Clarke SP, Sloane DM. Hospital staffing, organization, and quality of care: cross-national findings. International Journal of Quality in Health Care. 2012; 14 (1): 5-13. 